\title{
Combined ceftazidime and amikacin resistance among Gram-negative isolates in acute-onset postoperative endophthalmitis: prevalence, antimicrobial susceptibilities, and visual acuity outcome
}

Animesh Jindal ${ }^{1}$, Avinash Pathengay ${ }^{1 *}$, Manav Khera ${ }^{1}$, Subhadra Jalali², Annie Mathai ${ }^{2}$, Rajeev Reddy Pappuru², Raja Narayanan ${ }^{2}$, Savitri Sharma ${ }^{3}$, Taraprasad Das ${ }^{3}$ and Harry W Flynn $\mathrm{Jr}^{4}$

\begin{abstract}
Background: The purpose of this study is to evaluate the prevalence, antimicrobial susceptibilities, and visual acuity outcome of acute-onset postoperative Gram-negative bacterial endophthalmitis cases resistant to both ceftazidime and amikacin seen between 2005 and 2010 at L. V. Prasad Eye Institute, a tertiary care ophthalmic Centre in South India. Medical records of all patients with Gram-negative bacterial endophthalmitis resistant to both amikacin and ceftazidime between 1 January 2005 and 31 December 2010 were reviewed in this non-comparative, consecutive, retrospective case series. Favorable outcome was defined as a best-corrected visual acuity of $\geq 20 / 200$.

Results: Sixty five (39.6\%) of 164 culture-positive postoperative endophthalmitis were caused by Gram-negative organisms. Among these 65 isolates, 32 (49\%; 95\% confidence interval (Cl) 37\% to 61\%) were resistant to ceftazidime, 17 (26\%; 95\% Cl 15\% to 37\%) to amikacin, and 12 (18.5\%; 95\% Cl 9\% to 27\%) to both ceftazidime and amikacin. Eight Pseudomonas isolates, three Enterobacter isolates, and one Haemophilus isolate were resistant to both ceftazidime and amikacin. The isolates were sensitive to fluoroquinolones (42\%) and imipenem (50\%). Presenting visual acuity was light perception in 10 (83.3\%) cases. A final visual acuity $\geq 20 / 200$ was achieved in 5/12 (41.7\%) of these patients.

Conclusion: In the current study, Pseudomonas was the most common Gram-negative bacteria resistant to both amikacin and ceftazidime. The emergence of multidrug-resistant bacteria causing endophthalmitis is a matter of concern in India. Alternative antibiotics like imipenem or fluoroquinolones may be considered for the management of these resistant organisms.
\end{abstract}

Keywords: Antibiotics; Antibiotic resistance; Endophthalmitis; Gram-negative organisms; Amikacin; Ceftazidime; Vitrectomy

\footnotetext{
* Correspondence: avinash@lvpei.org

${ }^{1}$ L V Prasad Eye Institute, GMR Varalakshmi Campus, Visakhapatnam 530040,

India

Full list of author information is available at the end of the article
} 


\section{Background}

Gram-negative bacteria are less common cause of acuteonset endophthalmitis following cataract surgery [1]. Gram-negative organisms have been isolated in 26\% to $42 \%$ of patients with cataract surgery related to endophthalmitis in developing countries [1-3] as compared to $5.9 \%$ to $12.2 \%$ in developed countries [4-12]. The common Gram-negative organisms causing endophthalmitis include species of Pseudomonas, Haemophilus, Klebsiella, and Proteus. Intravitreal ceftazidime or amikacin are commonly used for the empiric treatment of Gram-negative organisms in endophthalmitis. In the Endophthalmitis Vitrectomy Study (EVS), 11\% of Gram-negative bacteria were resistant to both amikacin and ceftazidime [5]. The sensitivity of Gram-negative isolates reported from India is $61 \%$ to $63 \%$ to ceftazidime, $68 \%$ to $82 \%$ to amikacin, and $73 \%$ to $87 \%$ to ciprofloxacin [1,2]. Three decades ago (1980 to 1990), the sensitivity of Gram-negative isolates was $98 \%$ to amikacin and $100 \%$ to ceftazidime [13].

In the current study, the prevalence, antimicrobial susceptibilities, and visual acuity outcome of patients with acute-onset postoperative endophthalmitis is reported for Gram-negative bacteria which were resistant to both ceftazidime and amikacin.

\section{Methods}

Approval was obtained from the local institutional review board and the study followed the Declaration of Helsinki guidelines. Patients with acute-onset postoperative endophthalmitis caused by Gram-negative bacteria occurring between January 2005 and December 2010 and antimicrobial sensitivity data were obtained from the microbiology database. Of these, the isolates resistant to both ceftazidime and amikacin were included in the study and clinical records of these patients were reviewed and analyzed.

All patients were managed by the standard institutional protocol for management of acute endophthalmitis [14]. This essentially consisted of vitreous biopsy or vitrectomy, microscopy, and culture sensitivity of undiluted vitreous, intravitreal antibiotics (vancomycin $(1 \mathrm{mg} / 0.01 \mathrm{ml})+$ amikacin $(400 \mu \mathrm{g} / 0.01 \mathrm{ml}) /$ ceftazidime $(2.25 \mathrm{mg} / 0.01 \mathrm{ml}))$ with or without dexamethasone $(400 \mu \mathrm{g} / 0.01 \mathrm{ml})$. Intensive topical antibiotics (ciprofloxacin $0.3 \%$ half hourly) and corticosteroid (prednisolone acetate 1\%) were administered in all patients. Additional procedures such as repeat intravitreal antibiotics or pars plana vitrectomy/vitreous lavage were performed by the individual treating physicians without a predefined study protocol. Bacterial isolates were identified using Analytical Profile Index (API, Bio Meriux, Craponne, France). The antibiotic sensitivity was checked by the Kirby Bauer disc diffusion method. Anatomical success was defined as the intraocular pressure $\geq 10 \mathrm{mmHg}$ and best corrected visual acuity $\geq 20 / 200$.

\section{Results and discussion \\ Results}

A total of 510 acute-onset postoperative endophthalmitis patients were identified between 2005 and 2010. Sixty five $(39.6 \%$; $95 \%$ confidence interval (CI) $32.1 \%$ to $47.1 \%$ ) of 164 culture-positive postoperative endophthalmitis were caused by Gram-negative organisms. Among the 65 Gramnegative cases, 32 (49\%; 95\% CI 37\% to 61\%) cases were resistant to ceftazidime, 17 (26\%; 95\% CI 15\% to 37\%) were resistant to amikacin, and 12 (18\%; $95 \%$ CI $9 \%$ to $27 \%)$ were resistant to both ceftazidime and amikacin.

The mean age of these 12 patients was 61.67 years, ranging from 40 to 85 years. Median time from cataract surgery to onset of symptoms was 7.5 days (range 1 to 14 days). Ten of 12 patients presented with visual acuity of light perception, one had 20/600 and the other 20/80 (Table 1). Ten of 12 patients had hypopyon at presentation and optic disc was visible on indirect ophthalmoscopy in 3 of 12 patients.

The combined ceftazidime and amikacin resistance was commonly noted in Pseudomonas aeruginosa (8/38, $21.05 \%)$ followed by Enterobacter (3/5, 60\%) and Haemophilus $(1 / 3,33.3 \%)$ (Table 1). Out of these 12 isolates, five were susceptible to all fluoroquinolones and six were susceptible to imipenem (Table 2). In total, 11 of 12 isolates were susceptible to either of these two drugs. One Pseudomonas isolate was resistant to all the tested antimicrobials (Table 2).

A visual acuity $\geq 20 / 200$ at last follow-up was achieved in five $(41.7 \%)$ patients. Of the remaining seven patients with visual acuity $<20 / 200$, six went into phthisis and one eye developed thick epiretinal membrane with traction macular detachment. The patient with endophthalmitis caused by Haemophilus had a final visual acuity of hand motions despite presenting with visual acuity of $20 / 80$. In six (50\%) patients the IOL was explanted, which included four explantations during the primary surgery and in two patients during additional interventions. Nine patients required additional procedures such as repeat intravitreal antibiotic injection with or without vitrectomy (Table 1).

\section{Discussion}

The microbiological spectrum of acute-onset postoperative endophthalmitis from different parts of the world varies significantly. Staphylococcus sp. is the most common cause of acute-onset postoperative endophthalmitis following cataract surgery [6-8]. Series from Australia $[9,10]$, North America [6], and Europe [11,12] have reported $6 \%$ to $12 \%$ Gram-negative bacteria and in the EVS reporting Gram-negative bacteria was isolated in $5.9 \%(19 / 323)$ eyes [5]. The Indian studies, at $26 \%$ to $42 \%$, have reported higher incidences of Gram-negative bacterial infection [1,2]. Similarly, in a report from Turkey, a 
Table 1 Microbial organisms, interventions, and visual outcome

\begin{tabular}{|c|c|c|c|c|c|c|c|c|c|c|}
\hline S. No. & Eye & Organism & $\begin{array}{l}\text { Surgery to } \\
\text { symptoms } \\
\text { (days) }\end{array}$ & $\begin{array}{l}\text { Presenting } \\
\text { visual acuity }\end{array}$ & $\begin{array}{l}\text { Primary } \\
\text { intervention }\end{array}$ & $\begin{array}{l}\text { No. of } \\
\text { interventions }\end{array}$ & $\begin{array}{l}\text { Secondary } \\
\text { intervention } \\
\text { and intravitreal } \\
\text { antibiotics }\end{array}$ & $\begin{array}{l}\text { IOL } \\
\text { explant }\end{array}$ & $\begin{array}{l}\text { Duration of } \\
\text { treatment } \\
\text { (weeks) }\end{array}$ & $\begin{array}{l}\text { Final } \\
\text { BCVA }\end{array}$ \\
\hline 1 & OS & $\begin{array}{l}\text { Pseudomonas } \\
\text { aeruginosa }\end{array}$ & 11 & $20 / 600$ & $P P V+I O A$ & 6 & C+IOLex & Yes & 12 & $20 / 100$ \\
\hline 2 & OD & $\begin{array}{l}\text { Pseudomonas } \\
\text { aeruginosa }\end{array}$ & 9 & $L P$ & $P P V+I O A$ & 1 & None & No & 8 & $20 / 100$ \\
\hline 3 & OD & Enterobacter & 11 & $L P$ & PPV + IOA + IOLex & 1 & None & Yes & 1 & LP \\
\hline 4 & OS & Enterobacter & 2 & $L P$ & PPV + IOA + IOLex & 2 & Imip & Yes & 16 & $20 / 40$ \\
\hline 5 & OD & $\begin{array}{l}\text { Pseudomonas } \\
\text { aeruginosa }\end{array}$ & 5 & LP & PPV + IOA + IOLex & 2 & Imip & Yes & 12 & $20 / 100$ \\
\hline 6 & OS & Haemophilus & 1 & $20 / 80$ & $P P V+I O A$ & 2 & Chlor & No & 1 & $\mathrm{HM}+$ \\
\hline 7 & OS & $\begin{array}{l}\text { Pseudomonas } \\
\text { aeruginosa }\end{array}$ & 14 & $L P$ & $P P V+1 O A$ & 2 & PPV & No & 8 & $\mathrm{HM}+$ \\
\hline 8 & OD & Enterobacter & 5 & $L P$ & $P P V+10 A$ & 1 & None & No & 8 & LP \\
\hline 9 & OS & $\begin{array}{l}\text { Pseudomonas } \\
\text { aeruginosa }\end{array}$ & 14 & LP & $P P V+1 O A+1 O L e x$ & 2 & $C+D$ & Yes & 1 & LP \\
\hline 10 & OD & $\begin{array}{l}\text { Pseudomonas } \\
\text { aeruginosa }\end{array}$ & 7 & $L P$ & $P P V+1 O A$ & 9 & Imip + IOLex & Yes & 12 & $\mathrm{HM}+$ \\
\hline 11 & OD & $\begin{array}{l}\text { Pseudomonas } \\
\text { aeruginosa }\end{array}$ & 8 & $L P$ & $P P V+I O A$ & 2 & $C+D$ & No & 2 & LP \\
\hline 12 & OD & $\begin{array}{l}\text { Pseudomonas } \\
\text { aeruginosa }\end{array}$ & 10 & LP & $P P V+I O A$ & 4 & Imip $+D$ & No & 16 & $20 / 120$ \\
\hline
\end{tabular}

In patients with acute postoperative Gram-negative endophthalmitis resistant to both ceftazidime and amikacin. PPV, pars plana vitrectomy; IOA intraocular antibiotic; Imip, imipenem; C, ciprofloxacin; D, dexamathasone; Chlor, chloremphenicol; IOLex, intraocular lens explantation; LP, light perception; HM, hand motion; BCVA, best-corrected visual acuity.

higher rate of Gram-negative bacteria was reported at $35.1 \%$ of cases [3].

Current empirical therapies for endophthalmitis generally include vancomycin $(1.0 \mathrm{mg} / 0.1 \mathrm{ml})$ and ceftazidime $(2.25 \mathrm{mg} / 0.1 \mathrm{ml})$ or amikacin $(0.4 \mathrm{mg} / 0.1 \mathrm{ml})$. EVS reported the sensitivity rate of $89.5 \%$ for both amikacin and ceftazidime among Gram-negative isolates [5]. Another study from the USA has shown the sensitivity of Gram-negative bacteria to ceftazidime and amikacin at $99 \%$ and $100 \%$, respectively [15]. In India, susceptibility of Gram-negative bacteria to amikacin (68\% to $82 \%)$ and ceftazidime $(61 \%$ to $63 \%)$ is much lower $[1,2]$. We speculate

Table 2 Antibiotic susceptibility in patients with acute postoperative, Gram-negative endophthalmitis resistant to both ceftazidime and amikacin

\begin{tabular}{|c|c|c|c|c|c|c|c|c|c|c|c|c|}
\hline No. & Organism & $A$ & Cefa & Cefta & Chlor & Genta & Cipro & Gati & Imip & Oflox & Pipera & Ticar \\
\hline 1 & Pseudomonas aeruginosa & $\mathrm{R}$ & $\mathrm{R}$ & $\mathrm{R}$ & $\mathrm{R}$ & $\mathrm{R}$ & $\mathrm{S}$ & $\mathrm{S}$ & $\mathrm{R}$ & $\mathrm{S}$ & - & - \\
\hline 2 & Pseudomonas aeruginosa & $\mathrm{R}$ & $\mathrm{R}$ & $\mathrm{R}$ & $\mathrm{R}$ & $\mathrm{R}$ & $S$ & $\mathrm{~S}$ & $\mathrm{R}$ & $\mathrm{S}$ & $\mathrm{R}$ & $\mathrm{R}$ \\
\hline 3 & Enterobacter & $\mathrm{R}$ & $\mathrm{R}$ & $\mathrm{R}$ & $\mathrm{R}$ & $\mathrm{R}$ & $\mathrm{R}$ & $\mathrm{R}$ & $S$ & $\mathrm{R}$ & $\mathrm{R}$ & $\mathrm{R}$ \\
\hline 4 & Enterobacter & $\mathrm{R}$ & $\mathrm{R}$ & $\mathrm{R}$ & $\mathrm{R}$ & $\mathrm{R}$ & $\mathrm{R}$ & $\mathrm{R}$ & $S$ & $\mathrm{R}$ & $\mathrm{R}$ & $\mathrm{R}$ \\
\hline 5 & Pseudomonas aeruginosa & $\mathrm{R}$ & $\mathrm{R}$ & $\mathrm{R}$ & $\mathrm{R}$ & $\mathrm{R}$ & $\mathrm{R}$ & $\mathrm{R}$ & $S$ & $\mathrm{R}$ & $\mathrm{R}$ & $\mathrm{R}$ \\
\hline 6 & Haemophilus & $\mathrm{R}$ & - & $\mathrm{R}$ & $S$ & $\mathrm{R}$ & $S$ & $S$ & $\mathrm{R}$ & S & - & - \\
\hline 7 & Pseudomonas aeruginosa & $\mathrm{R}$ & - & $\mathrm{R}$ & $\mathrm{R}$ & $\mathrm{R}$ & $\mathrm{R}$ & $\mathrm{R}$ & $\mathrm{R}$ & $\mathrm{R}$ & $\mathrm{R}$ & $\mathrm{R}$ \\
\hline 8 & Enterobacter & $\mathrm{R}$ & - & $\mathrm{R}$ & $\mathrm{R}$ & $\mathrm{R}$ & $\mathrm{R}$ & $\mathrm{R}$ & $S$ & $\mathrm{R}$ & $\mathrm{R}$ & $\mathrm{R}$ \\
\hline 9 & Pseudomonas aeruginosa & $\mathrm{R}$ & - & $\mathrm{R}$ & $\mathrm{R}$ & $\mathrm{R}$ & $S$ & $S$ & $\mathrm{R}$ & $\mathrm{S}$ & - & - \\
\hline 10 & Pseudomonas aeruginosa & $\mathrm{R}$ & - & $\mathrm{R}$ & $\mathrm{R}$ & $\mathrm{R}$ & $\mathrm{R}$ & $\mathrm{R}$ & $\mathrm{S}$ & $\mathrm{R}$ & $\mathrm{R}$ & $\mathrm{R}$ \\
\hline 11 & Pseudomonas aeruginosa & $\mathrm{R}$ & $\mathrm{R}$ & $\mathrm{R}$ & $\mathrm{R}$ & $\mathrm{R}$ & $S$ & $S$ & $\mathrm{R}$ & $S$ & - & - \\
\hline 12 & Pseudomonas aeruginosa & $\mathrm{R}$ & $\mathrm{R}$ & $\mathrm{R}$ & $\mathrm{R}$ & $\mathrm{R}$ & $\mathrm{R}$ & $\mathrm{R}$ & $S$ & $\mathrm{R}$ & $\mathrm{R}$ & $\mathrm{R}$ \\
\hline
\end{tabular}

A, amikacin; Cefa, cefazolin; Cefta, ceftazidime; Chlor, chloramphenicol; Genta, gentamicin; Cipro, ciprofloxacin; Gati, gatifloxacin; Imip, imipenum; Oflox, ofloxacin; Pipera, piperacillin; Ticar, ticarcillin; $S$, sensitive; $R$, resistant. 
that widespread use of antibiotics along with cross transfer of multidrug resistance among Gram-negative organisms as a probable cause $[16,17]$.

There may be several mechanisms that contribute to the development of aminoglycoside resistance. These include the deactivation of aminoglycosides by aminoglycosidemodifying enzymes. Other mechanisms include the reduction of the intracellular concentration of aminoglycosides by changes in the outer membrane permeability which is usually a non-specific resistance mechanism, inner membrane transport, active efflux or drug trapping, the alteration of the $30 \mathrm{~S}$ ribosomal subunit target by mutation, and finally methylation of the aminoglycoside-binding site [18]. Efflux pumps and inhibition of drug intake are common components of multidrug-resistant Pseudomonas isolates which prevent accumulation of antibacterial drugs within the bacterium [19].

Ceftazidime is a third-generation cephalosporin and belongs to the beta lactam class of antibiotics. The most common mechanism of resistance to beta lactam antibiotics is by enzymatic deactivation of the drug. Beta lactamase produced by various Gram-negative bacteria renders them inherently resistant to most of the beta lactam antibiotics except third- and fourth-generation cephalosporins. Pseudomonas has an additional capability of producing AmpC $\beta$-lactamase (also known as cephalosporinase) whose activity is not inhibited by $\beta$ lactamase inhibitors including clavulanic acid, sulbactam, and tazobactam [20].

Among the fluoroquinolones, ciprofloxacin is generally the most effective drug against Pseudomonas. Other bacteria like Salmonella, Shigella, Neisseria, and Haemophilus are highly susceptible to ciprofloxacin regardless of whether the organisms produce $\beta$-lactamase or not [21]. The susceptibility profile of ciprofloxacin is reportedly superior to ceftazidime for Gram-negative organisms $[1,2,22]$. Resistance to fluoroquinolones in general and to ciprofloxacin in particular is reportedly low [23-25]. Also, in our study, ciprofloxacin was the drug of choice against Gram-negative bacteria [26]. In our database, out of the 65 cases of Gram-negative bacterial postoperative endophthalmitis, $77 \%$ isolates were sensitive to ciprofloxacin, and in the current series, nearly $42 \%$ of Gramnegative bacteria that were resistant to both ceftazidime and amikacin showed susceptibility to ciprofloxacin. Since the elimination half-life of intravitreal ciprofloxacin is short [27], oral administration may be considered in such patients. The intravitreal concentration of ciprofloxacin after oral administration has been demonstrated to be above the minimum inhibitory concentration (MIC-90, i.e., minimum antibiotic concentration inhibiting $90 \%$ of strains) of most of the organisms in inflamed eyes [28].

In the current study, $50 \%$ of the Gram-negative isolates which were resistant to both amikacin and ceftazidime were sensitive to imipenem. Imipenem has a broad spectrum of activity against both aerobic and anaerobic and Grampositive and Gram-negative bacteria including Pseudomonas and Enterococcus species. It acts by inhibiting cell wall synthesis of various Gram-positive and Gram-negative bacteria [29]. It is stable to hydrolysis by the common plasmid-mediated beta-lactamases produced by various bacteria and lacks cross resistance with penicillins and third-generation cephalosporins [30]. Intravitreal imipenem may limit intraocular inflammation and retinal tissue damage when given early in the course of Pseudomonas endophthalmitis [31]. It is generally nontoxic in animal models at concentrations that are far higher than the MIC 90 of 3.6 to $12.5 \mu \mathrm{g} / \mathrm{ml}$ against Pseudomonas infection and may offer promise in the treatment of endophthalmitis after intraocular surgery or perforating eye injuries [32].

In the EVS, $56 \%$ of eyes infected with Gram-negative bacteria regained 20/100 [4]. Multidrug resistance is more common in Gram-negative bacteria (78.6\%) compared to Gram-positive bacteria (21.4\%) [33]. The multidrug resistance and higher number of Pseudomonas in the current study may explain the poorer outcome in this study as compared to EVS.

There are certain limitations in this retrospective study. Firstly, antibiotic susceptibility in this study was tested by disc diffusion method and was not confirmed by MIC. Secondly, the number of cases included in the study is relatively small.

\section{Conclusions}

In conclusion, resistance to both amikacin and ceftazidime among Gram-negative isolates was not uncommon in the current study. Pseudomonas was the most common multidrug-resistant Gram-negative bacteria isolated and the visual acuity outcomes were generally poor. An alternative group of drugs like ciprofloxacin or imipenem may be considered for the management of these cases. Drug resistance is an emerging problem among Gram-negative isolates causing acute-onset postoperative endophthalmitis in India.

\section{Competing interests}

The authors declare that they have no competing interests.

\section{Authors' contributions}

AJ and MK carried out the data collection and data analysis and drafted the manuscript. AP is one of the treating physician and also carried out the correction of the manuscript. SJ, AM, RRP, RN, and TD are the other treating physicians. SS is the microbiologist. HWFJ corrected the manuscript. All authors read and approved the final manuscript.

\section{Author details}

${ }^{1} \mathrm{~L}$ V Prasad Eye Institute, GMR Varalakshmi Campus, Visakhapatnam 530040, India. ${ }^{2}$ Srimati Kannuri Santhamma Centre for Vitreoretinal Diseases, KAR Campus, LVPEI, KAR Campus, Hyderabad 500034, India. ${ }^{3}$ L V Prasad Eye Institutes, Bhubaneswar Eye Institute, Bhubaneswar, Odisha 751024, India. ${ }^{4}$ Department of Ophthalmology, Bascom Palmer Eye Institute, University of Miami, Miller School of Medicine, Miami, FL 33136, USA. 
Received: 7 May 2013 Accepted: 14 October 2013

Published: 25 October 2013

\section{References}

1. Kunimoto DY, Das T, Sharma S, Jalali S, Majji AB, Gopinathan U, Athmanathan S, Rao TN (1999) Microbiologic spectrum and susceptibility of isolates: part I. Post-operative endophthalmitis. Endophthalmitis Research Group. Am J Ophthalmol 128:240-242

2. Anand AR, Therese KL, Madhavan HN (2000) Spectrum of aetiological agents of postoperative endophthalmitis and antibiotic susceptibility of bacterial isolates. Indian J Ophthalmol 48:123-128

3. Altan T, Acar N, Kapran Z, Unver YB, Yurttaser S, Küçüksümer Y, Eser I (2009) Acute onset endophthalmitis after cataract surgery: success of initial therapy, visual outcomes, and related factors. Retina 29:606-612

4. Endophthalmitis Vitrectomy Study Group (1996) Microbiologic factors and visual outcome in the endophthalmitis vitrectomy study. Am J Ophthalmol 122:830-846

5. Hans DP, Wisniewski SR, Wilson LA, Barza M, Vine AK, Doft BH, Kelsey SF (1996) Spectrum and susceptibilities of microbiologic isolates in the Endophthalmitis Vitrectomy Study. Am J Ophthalmol 122:1-17

6. Benz MS, Scott IU, Flynn HW Jr, Unonius N, Miller D (2004) Endophthalmitis isolates and antibiotic sensitivities: a 6-year review of culture-proven cases. Am J Ophthalmol 137:38-42

7. $\mathrm{Ng} \mathrm{JQ}$, Morlet N, Pearman JW, Constable IJ, McAllister IL, Kennedy CJ, Isaacs T, Semmens JB (2005) Management and outcomes of postoperative endophthalmitis since the Endophthalmitis Vitrectomy Study: the Endophthalmitis Population Study of Western Australia (EPSWA)'s fifth report. Ophthalmology 112:1199-1206

8. Pijl BJ, Theelen T, Tilanus MA, Rentenaar R, Crama N (2010) Acute endophthalmitis after cataract surgery: 250 consecutive cases treated at a tertiary referral center in the Netherlands. Am J Ophthalmol 149:482-487

9. Kent DG (1993) Endophthalmitis in Auckland 1983-1991. Aust N Z J Ophthalmol 21:227-236

10. Lertsumitkul S, Myers PC, O'Rourke MT, Chandra J (2001) Endophthalmitis in the western Sydney region: a case-control study. Clin Experiment Ophthalmol 29:400-405

11. Montan P, Stenevi U, Lundstrom M, Thorburn W (2002) Endophthalmitis following cataract surgery in Sweden: the 1998 National Prospective Survey. Acta Ophthalmol Scand 80:258-261

12. Kamalarajah S, Silvestri G, Sharma N, Khan A, Foot B, Ling R, Cran G, Best R (2004) Surveillance of endophthalmitis following cataract surgery in the UK. Eye 18:580-587

13. Das T, Kunimoto DY, Sharma S, Jalali S, Majji AB, Rao TN, Goipinathan U (2005) Realtionship between clinical presentation and visual outcome in postoperative endophthalmitis in south central India. Indian J Ophthalmol 53:5-16

14. Irvine WD, Flynn HW Jr, Miller D, Pflugfelder SC (1992) Endophthalmitis caused by gram-negative organisms. Arch Ophthalmol 110:1450-1454

15. Recchia FM, Busbee BG, Pearlman RB, Carvalho-Recchia CA, Ho AC (2005) Changing trends in the microbiologic aspects of postcataract endophthalmitis. Arch Ophthalmol 123:341-346

16. Khajuria A, Praharaj AK, Kumar M, Grover N (2013) Emergence of NDM - 1 in the clinical isolates of Pseudomonas aeruginosa in India. J Clin Diagn Res 7:1328-1331

17. Kumarasamy KK, Toleman MA, Walsh TR, Bagaria J, Butt F, Balakrishnan R, Chaudhary U, Doumith M, Giske CG, IIfan S, Krishnan P, Kumar AV, Maharjan S, Mushtaq S, Noorie T, Paterson DL, Pearson A, Perry C, Pike R, Rao B, Ray U, Sarma JB, Sharma M, Sheridan E, Thirunarayan MA, Turton J, Upadhyay S, Warner M, Welfare W, Livermore DM, Woodford N (2010) Emergence of a new antibiotic resistance mechanism in India, Pakistan, and the UK: a molecular, biological, and epidemiological study. Lancet Infect Dis 10:597-602

18. Gad GF, Mohamed HA, Ashour HM (2011) Aminoglycoside resistance rates, phenotypes, and mechanisms of Gram-negative bacteria from infected patients in upper Egypt. PLoS One 6:e17224

19. Tenover FC (2006) Mechanisms of antimicrobial resistance in Bacteria. Am J Med 119:S3-S10

20. Strateva T, Yordanov D (2009) Pseudomonas aeruginosa - a phenomenon of bacterial resistance. J Med Microbiol 58:1133-1148

21. Blondeau JM (2004) Fluoroquinolones: mechanism of action, classification, and development of resistance. Surv Ophthalmol 49:S73-S78
22. Hui M, Kwok AK, Pang CP, Cheung SW, Chan RC, Lam DS, Cheng AF (2004) An in vitro study on the compatibility and precipitation of a combination of ciprofloxacin and vancomycin in human vitreous. Br J Ophthalmol 88:218-222

23. Alexandrakis G, Alfonso EC, Miller D (2000) Shifting trends in bacterial keratitis in south Florida and emerging resistance to fluoroquinolones. Ophthalmology 107:1497-1502

24. Taban M, Behrens A, Newcomb RL, Nobe MY, Saedi G, Sweet PM, McDonnell PJ (2005) Acute endophthalmitis following cataract surgery: a systematic review of the literature. Arch Ophthalmol 123:613-620

25. Aaberg TM Jr, Flynn HW Jr, Schiffman J, Newton J (1998) Nosocomial acuteonset postoperative endophthalmitis survey. A 10-year review of incidence and outcomes. Ophthalmology 105:1004-1010

26. Duggirala A, Joseph J, Sharma S, Nutheti R, Garg P, Das T (2007) Activity of newer fluoroquinolones against Gram-positive and Gram-negative bacteria isolated from ocular infections: an in vitro comparison. Indian J Ophthalmol 55:15-19

27. Pearson PA, Hainsworth DP, Ashton P (1993) Clearance and distribution of ciprofloxacin after intravitreal injection. Retina 13:326-330

28. Oztürk F, Kortunay S, Kurt E, Ilker SS, Basci NE, Bozkurt A (1999) Penetration of topical and oral ciprofloxacin into the aqueous and vitreous humor in inflamed eyes. Retina 19:218-222

29. Williams RJ, Yang YJ, Livermore DM (1986) Mechanisms by which imipenem may overcome resistance in gram-negative bacilli. J Antimicrob Chemother 18:9-13

30. Pastel DA (1986) Imipenem-cilastatin sodium, a broad-spectrum carbapenem antibiotic combination. Clin Pharm 5:719-736

31. Alfaro DV 3rd, Hudson SJ, Kasowski EJ, Barton CP, Brucker AJ, Lopez JD, Beverly DT, King LP (1997) Experimental pseudomonal posttraumatic endophthalmitis in a swine model. Treatment with ceftazidime, amicacin, and imipenem. Retina 17:139-145

32. Loewenstein A, Zemel E, Lazar M, Perlman I (1993) Drug-induced retinal toxicity in albino rabbits: the effects of imipenem and aztreonam. Invest Ophthalmol Vis Sci 34:3466-3476

33. Pathengay A, Moreker MR, Puthussery R, Ambatipudi S, Jalali S, Majji AB, Mathai A, Husssain N, Dave V, Sharma S, Das T (2011) Clinical and microbiologic review of culture proven endophthalmitis caused by multidrug resistant bacteria in patients seen at a tertiary eye care centre in southern India. Retina 31:1806-1811

\section{doi:10.1186/1869-5760-3-62}

Cite this article as: Jindal et al:: Combined ceftazidime and amikacin resistance among Gram-negative isolates in acute-onset postoperative endophthalmitis: prevalence, antimicrobial susceptibilities, and visual acuity outcome. Journal of Ophthalmic Inflammation and Infection 2013 3:62.

\section{Submit your manuscript to a SpringerOpen ${ }^{\circ}$ journal and benefit from:}

- Convenient online submission

- Rigorous peer review

- Immediate publication on acceptance

- Open access: articles freely available online

- High visibility within the field

- Retaining the copyright to your article

Submit your next manuscript at springeropen.com 